Herzog Csilla ${ }^{1}$ - Racsko Réka ${ }^{2}$

1 Eszterházy Károly Egyetem, Kommunikáció és Médiatudományi Tanszék

2 Eszterházy Károly Egyetem, Médiainformatika Intézet, Humáninformatika Tanszék

\title{
Táblagép az osztályteremben
}

\section{Az új tanulási környezettel kapcsolatos tanári tapasztalatok}

Az egri Eszterházy Károly Fóiskola Gyakorló Általános Iskola és

Gimnáziumban már a 2011/2012-es tanév elsó félévétól megkezdôdhettek azok a táblagépes módszertani kísérletek, melyek

során a különbözó kutatócsoportok számára lehetôvé vált a mobilkommunikációs eszközök (táblagépek) oktatási folyamatba való bevonásának, alkalmazásának különbözố aspektusok szerinti

vizsgálata. Számos kutatás zajlott az elmúlt években a Hozd magaddal a saját eszközöd (BYOD - Bring Your Own Device) koncepció közoktatásban ${ }^{1}$ történó bevezetésével, valamint a tanulók személyes tanulási környezetének kialakitásával kapcsolatban. Az alkalmazott módszertani modell ezen kísérletekben a hozzáférés 1:1 modelljére (Racsko, Kis-Tóth és Gulyás, 2014) épült, és hosszú távon az oktatás digitális átállását (D-Transform)² célozza meg.

elen írás szerzői főképp aziránt érdeklődtek, hogy az oktatási folyamatban alkalmazott újmédia-eszközök a pedagógusok szemszögéből milyen megítélésüek, milyen tapasztalatokról számolnak be e téren a technológia oktatásban történő alkalmazásáról. A kutatások jelentős része általában a tanulóra fókuszál, és az oktatási folyamat egyéb szereplőinek, a szülőknek és a pedagógusoknak kisebb teret engednek a tapasztalatokat illetően. Ezen hiányosság feloldására a tanulmányban bemutatásra kerülö fókuszcsoportos interjú során tehát arra kerestük a választ, hogy az elektronikus tanulási környezetben alkalmazott tanulási-tanítási modellek milyen lehetőségeket rejtenek, és adott esetben milyen kihívásokat állítanak a pedagógusok elé, akik a mindennapi munkájukban alkalmazzák az információs és kommunikációs technológia eszközeit, megteremtve a tudáson alapuló társadalom jövőjét.

\section{Tanulási-tanítási modellek az új tanulási környezetben}

Az új technológiákkal kapcsolatos fejlesztések nem csupán a versenyszféra, hanem az oktatás területén is éreztetik hatásukat. Az innovációkban érintett vállalatok mintegy „laboratóriumként”, kísérleti terepként tekintenek az iskolai közegre. A jelenlegi oktatási rendszert többnyire az ipari társadalmak iskolája jellemzi, amelyben bár jelen van az információtechnológia, mégsem azzal a funkcióval, amelyet az információs és tudásalapú társadalom neki szán. Tanulmányunkban az elektronikus tanulási környezettel kapcsolatos tanulási-tanítási modellek bemutatására vállalkozunk. 
A BYOD, azaz a „Hozd magaddal a saját eszközöd” szemlélet arra épül, hogy a tanulók tanulás közben is végezhetnek személyes tevékenységeket, és szabadidejükben is tanulhatnak, azaz maguk osztják be az idejüket, amely hozzájárulhat a tanulással szembeni pozitív attitüd és a személyes tanulási környezet kialakításához. A modell a folyamatos és hatékony tanulást segíti, amelynek köszönhetően a tanulók különböző helyszínekről és eszközökről elérhetik a tananyagot (curriculum) és a különféle oktatási alkalmazásokat, valamint interakcióba léphetnek a pedagógussal.

A Hozd magaddal a saját eszközöd modell az ipari szférából került át az oktatás területére. A koncepció iránti fogékonyságot és érdeklődést jól mutatja, hogy az elmúlt években tért hódítottak az erre épülő hazai és nemzetközi pedagógiai kutatások és iskolakísérletek. ${ }^{4}$

A modell alapelve, hogy a tanulók a mindennapokban már rutinosan használt IKT-eszközeiket (pl. okostelefon, iPpad) az iskolában, a tanítás-tanulás folyamatában is alkalmazzák, és akár a személyes tanulási környezet kiépítése is megvalósul rajtuk. További előnye, hogy a tanulók állandóan az eszköz birtokában vannak, így ezen keresztül az információelérés, az adatokhoz való hozzájutás és a folyamatos kapcsolattartás is megvalósulhat. Ezek eredményeképpen hozzájárulhat a trialogikus tanuláselmélet (Paavola és Hakkarainen, 2005, idézi Molnár és Kárpáti, 2009) kialakításához, és az innovatív tanulóközösségek eredményes megvalósításához.

Egyre több iskola vezeti be a BYOD modellt, és engedélyezi tanulóinak a saját eszköz vagy eszközök tanulási célú használatát. Természetesen kezdetben segíteni kell a tanulókat abban, hogy az eszközöket birtokolhassák. (Ez azt jelenti, hogy az iskola biztosítja valamennyi tanuló számára.) A bevezetésnek két modellje, gyakorlata figyelhető meg: az egyik esetben a tanulók egy elöre megadott listából választhatják ki az eszközt, amelyet vagy az iskola, vagy valamely szponzor finanszíroz, a másik esetben a tanulók a saját eszközüket viszik be az oktatási folyamatba.*

Ehhez kapcsolódik, hogy Japánban és Dél-Koreában néhány évvel ezelőtt elkezdődött egy mára már nagy sikereket elért szisztematikus fejlesztés, amelyben az infrastruktúra kiépítését helyezték elötérbe. Ez magában foglalta a korszerü IKT-eszközök bevezetését, valamint a digitális könyvtárak oktatásba történő integrálását. A módszer neve információorientált oktatás. A modell egy jelentős lépés lehet az együttmüködő intézményekben a tudás közös felületen történő integrációjára és az eszközök összekapcsolására. Hasonló jó gyakorlat zajlik Dániában is, azonban látható, hogy az eszköz megléte csak az első lépés a digitális átállásban.

\section{1:1 modell (Racsko, Kis-Tóth, \& Gulyás, 2014)}

Az elektronikus tanulási környezet rendszerén belül (Komenczi, 2009) a személyes tanulási környezetek kialakításában hangsúlyos BYOD-modell mellett (Chatti, Agustiawan, Jarke \& Specht, 2012; Dabbagh \& Kitsantas, 2012) érdemes a hozzáférési modellként definiált 1:1 modellröl is említést tenni. Az 1:1 modell oktatási környezetben a 90-es években jelent meg, amelynek keretében a tudományos intézetek és a felsőoktatási intézmények internetképes eszközt adtak a diákoknak, a digitális tartalmak, tananyagok, jegyzetek eléréséhez.**

* Egy olyan kezdeményezés is megjelent, amelyben bármely internetes csatlakozásra képes eszközt bevihetnek a tanulók, , azonban ezek alkalmazási lehetőségei korlátozottak.

** Az Intel, One Laptop Per Child projektje lényegében erre épül. 
Előnye, hogy egyenlő hozzáférést és feltételeket biztosít a tanulóknak, egyszerü a szoftverek frissítése, a hálózat kiépítése, a tanulók munkájának nyomon követése (pl. felügyeleti szoftverrel), és a tanulóktól tudatos online viselkedést követel meg.

Kezdetben ennek egy ellenpontjaként tekintettek a BYOD-modellre, azonban ez mára már az oktatási infrastruktúra egyik paradigmaváltása lehet. Az 1:1 modell ugyanis jelentős intézményi beruházást követel, hiszen az eszközök megvásárlása, karbantartása, szoftver-licenszek beszerzése, fejlesztési költségek, javítások jelentős összegeket emésztenek fel, és humáneröforrás-igényük is van.

A koncepciót a vonatkozó irodalmakban elsősorban a táblagépekkel való oktatás keretrendszereként írják le, amely az új médiatechnológiák erősségeire épít, vagyis a tartalmak valamiféle csatornájaként, modelljeként és az azonnali visszacsatolás eszközeként értelmezhető. A legtöbb esetben ezen hozzáférés aszinkron módon történik, és önállóan megy végbe (lásd 1. számú ábra). A táblagépek oktatásban való használatánál a legfontosabb tényező a tanulási folyamat újragondolása, melynek során minden fél számára biztosított az egy tanuló - egy képernyő hozzáférés lehetősége, felkínálva ezzel a mobilitás és a személyre szabott tanulási környezetet.

Az 1:1 modell jól összecseng a BYOD-modell koncepciójával. Főbb elemei mellett megnevezésre kerülnek a tanórai tevékenység révén fejlesztendő készségek és képességek is (lásd 1. ábra):

1. Virtuális közösségeken keresztül tanulási tartalmakhoz történő hozzáférés biztosítása.

2. Digitális tartalomszolgáltató csatornák ellenőrzött és nem ellenőrzött tartalmaihoz való hozzáférés biztosítása.

3. Az intuitív, ösztönző modellekhez/alkalmazásokhoz való hozzáférés biztosítása.

4. A személyre szabott visszacsatolás lehetővé tétele.

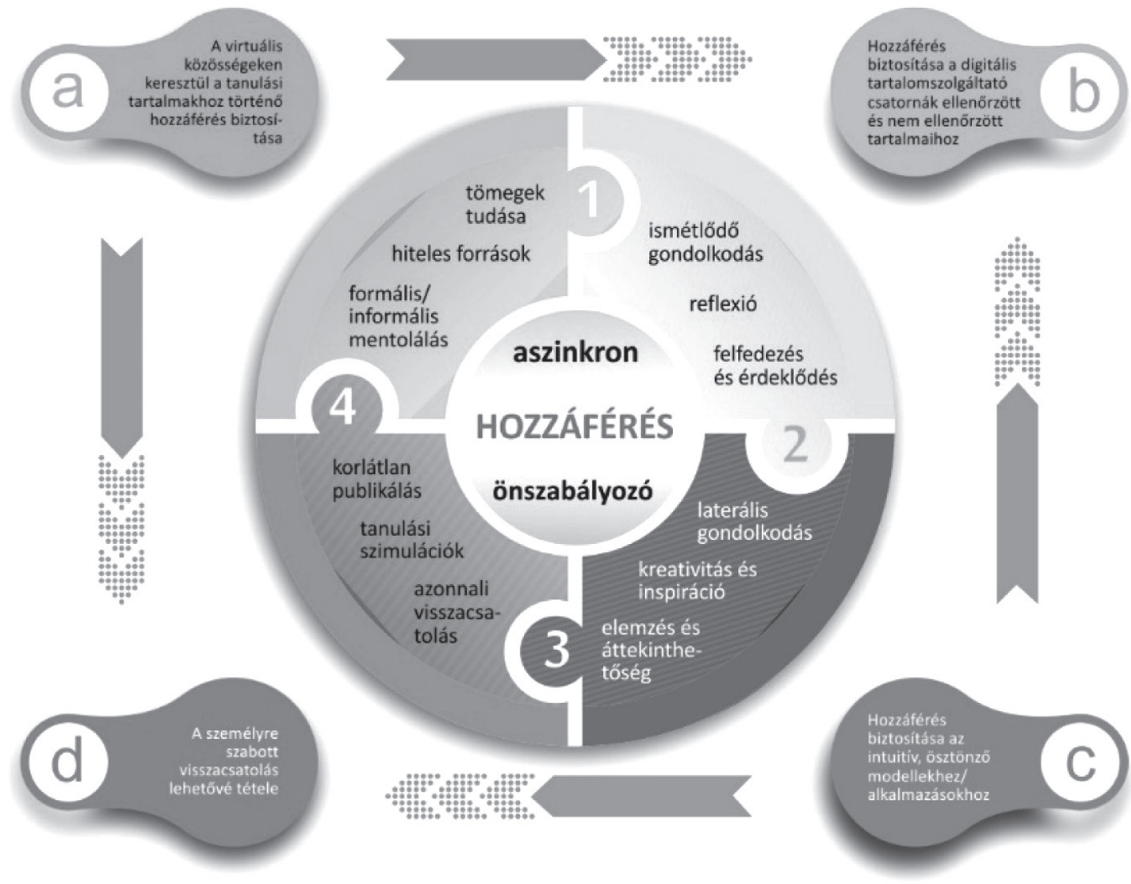

1. ábra. A hozzáférés 1:1 modellje 
A digitális tartalmakkal való folyamatos (24/7) kapcsolat a tanulási folyamat önszerveződővé és személyes irányításúvá válását segíti elő. A tanulók a világhálón olyan információkhoz is hozzájuthatnak, amelyek fejlesztik a felhasználók információs műveltségét, és amellett, hogy hatást gyakorolnak a tudatos és kritikus információfogyasztásra, képesek a felfedezéses és más tevékenységekbe ágyazott tanulás készségeit aktivizálni. Hosszú távon ezt fejleszti a hozzáférés 1:1 modellje.

\section{R2D2 modell (Racsko, 2012)}

A tanulási-tanítási környezet kialakításánál több tényezőt is érdemes figyelembe venni; ezek közül a két leglényegesebb az életkori sajátosságok és a tanulási szokások. Az alábbi ábrát Curtis J. Bonk és szerzőtársa Ke Zhang (Bonk \& Zhang, 2008, idézi Kis-Tóth 2009) alkotta meg. A kutatók szerint a különböző tanulói típusok más és más jellemzők mentén írhatók le, de elkülöníthetők a tanulási tevékenységek, illetve az általuk használt online erőforrások, eszközök tekintetében is (lásd 2. ábra).

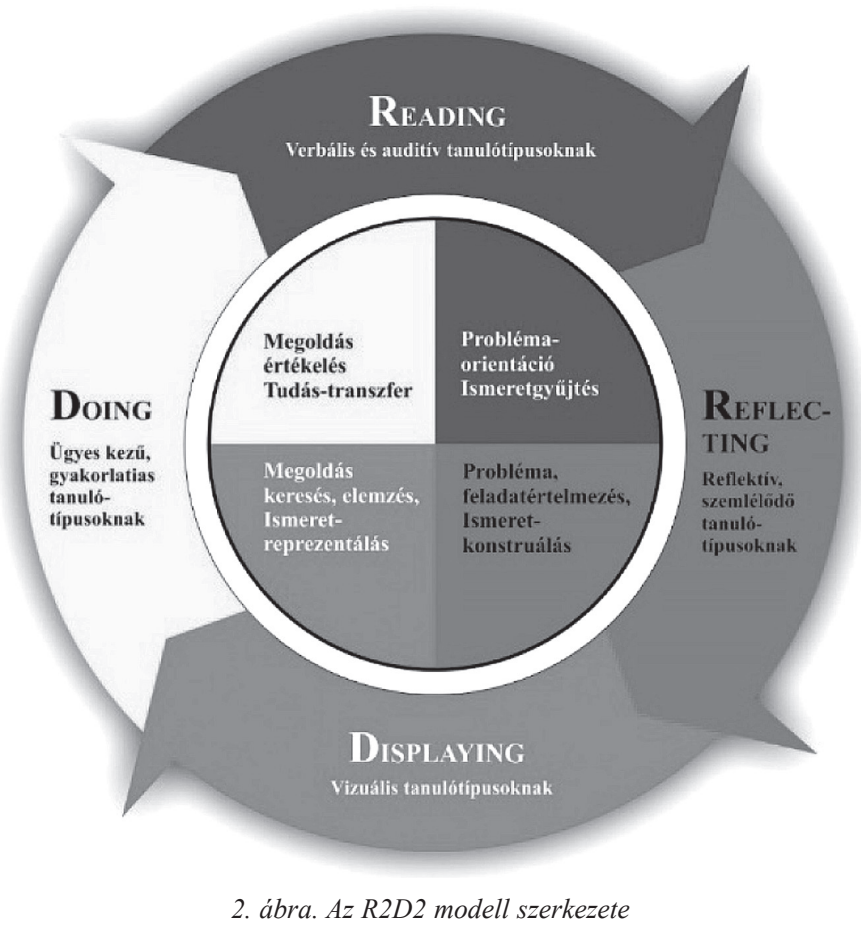

A tanulók egy része hallás útján szereti elsajátítani a tananyagot, mások inkább az olvasást részesítik előnyben. Vannak olyan diákok, akik gyakorlati úton, tevékenységek révén képesek inkább az ismeretek elmélyítésére, míg az iskolások további típusa az elmélkedést választja.

A szerzőpáros hangsúlyozza, hogy a négy tanulótípus nem elszigetelten van jelen a tanulóknál, azaz a legtöbb tanulóra vagy egy-egy tanulási fázisban, vagy életkorban jellemző mindegyik típus. A modellben a négy tanulótípus jellemzői mellett egyenként 25 tevékenység is megjelenik, amely az online erőforrások lehetőségeit kategóriákba rendezve tartalmazza. 
A verbális és auditív tanulótípusra $(\mathrm{R})$ jellemző, hogy előnyben részesítik a szóbeli vagy írott magyarázatokat. Így számukra azok az alábbi online erőforrások az elsődlegesek: podcast, online PDF-dokumentumok, hangfájlok, Power Point prezentációk, online portálok, kurzus-összefoglalók, súgók, GYIK, online újságok, e-könyvek, online könyvtárak, online értesítők, kézikönyvek.

A reflektív, szemlélődő tanuló típushoz $(\mathrm{R})$ tartozók előnyben részesítik a kifejező, reflexív, megfigyelö, látható tanulási formát, szeretik a könnyen eldönthető, megbízható ítéleteket, axiómákat, szeretnek egy dolgot több nézőpontból szemlélni, úgy, hogy abba belefoglalják saját megfigyeléseiket, szeretnek önreflexiót, áttekintést és reflektív összefoglalót írni. Számukra a blog, azonnali üzenetküldő szolgáltatás, online vizsgák, elektronikus portfólió, aszinkron viták/megbeszélések, reflektív alkalmazások, online áttekintések, öntesztelő támogatások, szakmai videók, előadások a leghatékonyabb online erőforrások.

A vizuális tanulótípus (D) kedveli a vizuális, képi információkat, úgymint diagramokat, fogalomtérképek, folyamatábrák, idővonalak, képek, filmek, bemutatók, infografikák. A vizuális tartalmakban bővelkedő világhálón számos online örforrás közül választhatnak: fogalomtérkép és idővonal-készítő alkalmazások, interaktív hírportálok, virtuális utazások, túrák, animációk, videokonferenciák, online videók, online grafikonok, diagramok, folyamatábrák, vizualizációs eszközök, videoblogok, vodcastek.

A tevékenység útján tanulók (ügyes kezü, gyakorlatias) (D) a mozgásos, azaz a taktilis és kinezikus típusú tanulást részesítik előnyben, így számukra a szerepjátékok, kooperatív játékok, szimulációkat, kreatív mozgásokat és táncot, több érzéket használó tevékenységeket, lehetnek megfelelőek. Az ezekhez tartozó online erőforrások: szimulációk, online játékok, wikik, digitális történetmesélés és filmkészítés, valós idejű események, video-forgatókönyvek, kérdőíves felmérések, folytatásos történetek, csoport- és kollaboratív eszközök, szerepjátékok. A területhez ma már kiterjesztett valóság (AR-augmented reality) hardver- és szoftvereszközök is megjelentek a piacon, amelyek a tanulás-tanítás folyamatába is beépíthetők.

A tanulótípusok definiálása mellett meghatározták, hogy milyen kompetenciák fejleszthetők az egyes területeken, illetve az egyének az adott tanulási fázisban melyekkel rendelkeznek. A verbális és auditív tanulótípusra a problémaorientáció, az ismeretgyüjtés és a megoldás keresése és annak értékelése a jellemzö, oly módon, hogy a tudást másokkal megosztva gyarapítja. A reflektív, szemlélődő típusra szintén jellemző a problémaközpontúság és az ismeretgyüjtés, ám a probléma- és feladatelemzö, több oldalról történö értelmezése, áttekintése és az ismeretek, tartalmak létrehozása inkább jellemző. A vizuális tanulótípus szintén problémaérzékeny, és az ismeretkonstruálás fontos számára azonban emellett a megoldás keresése, elemzése és annak reprezentálása szintén lényeges. Az ügyes kezü, gyakorlatias típusra ez utóbbi szintén jellemző, de úgy, hogy közben értékeli is a magtalált megoldást. Az ábrából jól látjuk, hogy egy körkörös, és folyamatelvü gondolkodást tükröz a modell, így az prioritások, fejlesztendő kompetenciák is átfedésben vannak, és folyamatosan, dinamikusan változnak a környezet hatására.

\section{Humán Teljesítményt Támogató Technológia (HPT) (Racsko, 2014)}

A humán teljesítménytámogató technológia (Human Performance Technology) fogalma az oktatástechnológia területén bontakozott ki az 50-es, 60-as években. A 70-es években a gyakorlati alkalmazás révén terjedt el széles körben (Dean és Ripley, 1997; Stolovitch és Keeps, 1999; Gilbert, 2007). Később a humán teljesítménytámogatás és az oktatórendszerek tervezésének (Instructional Systems Design - ISD) területe kettévált.

A rendszer az egyén, a csoport és a szervezet szintjén (ISPI) három alapvető folyamat kombinációját foglalja magában: a teljesítményelemzést, az okok feltárását, valamint a 
beavatkozás folyamatának kiválasztását. Több helyen Human Performance Improvement (HPI), azaz humán teljesítményfejlesztés néven ismeretes, és számos más teljesítménytámogató rendszerhez hasonlatos, bár ezeknél komplexebb belső tartalommal. Fókuszában a teljesítmény javítása áll a társadalom, a szervezet és az egyén szintjén is értelmezve. Az oktatási eredményesség intézményesült megjelenése a 20. század végére tehető, ugyanis 1990-ben jött létre a Congress for School Effectiveness Improvement (ICSEI) szervezet, illetve folyóiratuk, a School Effectiveness and School Improvement (SESI).

A HPT alapja az a feltételezés, miszerint az emberi teljesítmény több oldalról is mérhető. A szükséges adatok gyüjtése empirikus módszerekkel, megfigyelések és kísérletek által történik, melynek célja a döntéshozók tájékoztatása. Ezen mérések eredménye a célzott és eredményorientált, költséghatékony változások bevezetése a teljesítményjavítás érdekében reaktív és proaktív módon egyaránt (Chyung, 2008). A HPT három fő komponense: az ember, a teljesítmény és a technológia, ezek összetartozó, szoros egységben állnak egymással (lásd 3. ábra).

\begin{tabular}{|l|l|}
\hline Ember (Human) & Egy szervezetet egyének és csoportok alkotnak \\
\hline Teljesítmény (Performance) & Tevékenységek és mérhető eredmények \\
\hline Technológia (Technology) & $\begin{array}{l}\text { A gyakorlati problémák megoldására rendszeres és } \\
\text { szisztematikus megoldásokat alkalmaznak }\end{array}$ \\
\hline
\end{tabular}

3. ábra. A Humán Teljesitménytámogató Technológia három összetevője

A HPT több tudományterületet használ módszereiben, például a viselkedéspszichológiát, a pedagógiai/oktatási rendszertervezést, a szervezetfejlesztést, valamint az emberierőforrás-menedzsmentet. A módszer lényege, hogy a jelenlegi teljesítmény elemzése során beazonosítják azokat a teljesítményben jelentkező szakadékokat, hiányosságokat, amelyeket később a változásmenedzsment és a teljesítménynövelés egyéb módszerei során fejleszt, majd ennek eredményét értékeli. A folyamat a teljesítményfejlesztési stratégiára épül. Általános félreértés, hogy a technológián az infokommunikációs eszközöket értik. Mint a 3. ábra is mutatja, a technológia ebben az értelemben tudományos ismeretek, tudáselemek gyakorlati alkalmazását jelenti, például az iparban. A tudományos ismeretek elsősorban müszaki irányultságú, a mérnöki és alkalmazott tudományok területéröl származnak.

A fogalommal az 1990-es évektől foglalkozik behatóbban az akadémiai szféra, és számos intézmény képzési programjába is bekerült, diplomás és posztgraduális képzések formájában. A 90-es évek végén azonban (Stolovitch \& Keeps, 1999) egyre nagyobb szakadék keletkezett a humán teljesítménytámogató technológia gyakorlati alkalmazása és az akadémiai/kutatói szféra munkái között, ennek orvoslására számos, ezzel kapcsolatos kutatás vette kezdetét. Az oktatási intézmények hatékonyságának mérésére intézményesült képzés hazánkban a 2000-es években jelent meg a szakirányú továbbképzési szakok formájában, és a szakvizsgával egyenértékü továbbképzési szakoknál, mint a tanügyigazgatási szakértő vagy a közoktatás-vezetői képzés. ${ }^{5}$ Jól példázza a fogalmak tisztázatlanságát, hogy a teljesítményfejlesztés nemzetközi szervezete csak többszöri névváltoztatás után, 1995-ben vált véglegessé, International Society for Performance Improvement (ISPI), azaz a Teljesítménytámogatás Nemzetközi Szervezete néven (Chyung, 2008), amely a mai napig támogatja tevékenyégével a fejlesztést.

Bár a humán teljesítménytámogató technológia elsősorban az ipar és a termelési szektor területén terjedt el, tanulmányunk folytatásában jól láthatjuk, hogy az oktatás, elsősorban az oktatási rendszerek és az egyén szintjén megjelenő hatékonyságvizsgálatokban is megjelennek bizonyos elemei.

Az oktatási és iskolai környezet, azaz a tanulók, a tanárok, iskolavezetők értékelésére és mérésére az OECD-országokban a 2013-as mérésekből is jól láthatóan egyre nagyobb hangsúlyt fektetnek (Synergies é. n., 2013, idézi Gyökös és Szemerszki, 2013). Az elmúlt 
évek nemzetközi kutatásai az iskolai müködés sikertényezőit két irányzat mentén azonosítják. Az egyik föképp a tanulási kimenetek (learning outcomes) (Setényi, 2013) oldaláról értékeli a sikeres oktatási intézményt, de nagy hangsúlyt helyez a tanulási és a tanítási célok megvitatása és kitüzése szempontjaira is. Ezen folyamatokban a bemenet és az eredmények átgondolása az elszámoltathatóság a fő mozgatórugó.

A másik nagy irányzat Scheerens, Glas és Thomas (2003) munkásságához köthetö, akik OECD-s, amerikai, angol és holland kutatások és empirikus felmérések szintetizálásával 16 olyan faktort azonosítottak, melyek minden eddiginél erősebb hatással vannak az iskolai működés minőségére, sikerére. A kutatók szerint az eredményes iskolához pl. a humán erőforrással szembeni magas elvárásokra és teljesítményorientációra van szükség, a tanulási idő hatékony kihasználására, a tanterv prioritásainak megfelelö ismeretére és minőségére, hatékony vezetési stratégiára, a tantestületen belüli jó munkahelyi és iskolai, tantermi klímára, konszenzusra és kohézióra. Biztosítani kell a lehetőséget a strukturált tanításra és differenciálásra, illetve a hatékony időgazdálkodást is figyelembe kell venni. A szakemberek ugyanakkor hangsúlyozzák, hogy törekedni kell a folyamatos megerösítésre, értékelésre és visszajelzésre is.

Több kutatásban (például Sahlberg 2011; Hargaves 2012) vizsgálták továbbá, hogy milyen faktorok kellenek ahhoz a sikeres oktatási rendszerhez, amely a digitális átállást is magában foglalja. Az eredmények szerint a pedagógusok társadalmi megbecsültségén kívül a folyamatos képzést, új módszertani elemek megismerését és alkalmazását lehet megnevezni, amely a korszerü, elsősorban IKT-eszközök adta lehetőségek és módszerek minél mélyebb integrációját jelenti.

A hazai szakirodalomban az elektronikus tanulási környezet adta lehetőségeket a következőképpen foglalhatjuk össze (Bedö \& Schlotter, 2008, old.: 11-24):
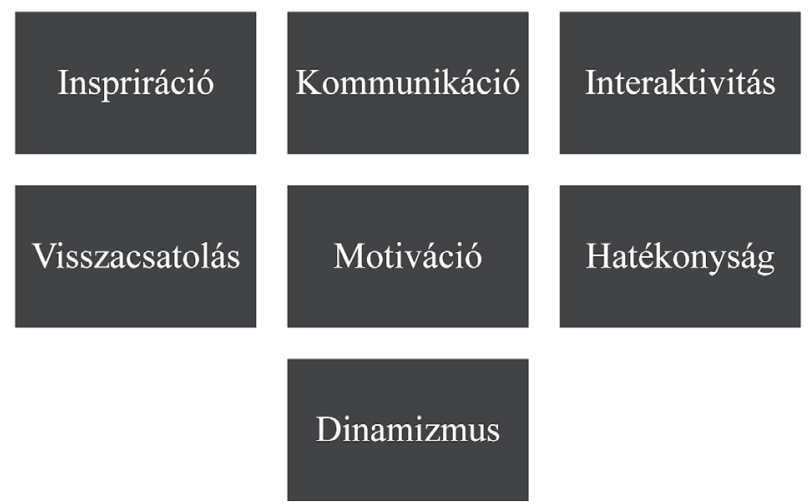

4. ábra-. Az új tanulási környezetben a legfontosabb tanári ismérvek

Korunk megváltozott tanulási környezetében - a meglévőek mellett - olyan alapkészségeket is szükséges elsajátítani, amelyek a digitális állampolgárság feltételei. Ilyenek pl. a kreativitás fejlesztése, a tanulók vizuális képességeinek kiaknázása, a tudatos és kritikus médiahasználat, valamint az immunokompetencia, azaz a problémákra adott rugalmas megoldások keresése, a dinamikus problémakezelés minél magasabb szintü képességének alkalmazása. ${ }^{6}$ Ezen elvárások azonban nem valósulhatnak meg anélkül, hogy a pedagógusok (pro)aktív részesei ne legyenek a digitális átalakításnak, valamint anélkül, hogy célzott és tervszerü képzése-, továbbképzése ne képezné az oktatási folyamat részét.

A sikerfaktorok számbavétele után tanulmányunk folytatásában rátérünk az új tanulási környezetben lefolytatott kutatásunk ismertetésére. 


\section{A kutatás előzményei (Herzog, Racsko, \& Kis-Tóth, 2014)}

Vizsgálatunk alapkutatás jellegü, amely során többféle módszert alkalmaztunk: a tanulói teljesítmények összehasonlítása érdekében a pedagógiai kísérletbe bevont osztályok (a 3., 6. és 9. évfolyamosok) félévi és év végi érdemjegyeit a párhuzamos tanulócsoportok eredményeivel vetettük össze. Kiegészítve kvantitatív kutatásunkat, saját fejlesztésü mérőeszközöket is alkalmaztunk: a tanulói és szülői kérdőívekkel azokat az attitüdöket kívántuk feltárni, amelyek az informatikával, illetve az új médiumokkal, és azok oktatási folyamatban való alkalmazásával kapcsolatosak. A tanári fókuszcsoportok segítségével pedig az empirikus eredmények hátterében húzódó mélyebb összefüggéseket igyekeztünk feltárni.

Az IKT-eszközökkel támogatott oktatási folyamatok tanulói, iskolai és szülői tapasztalatait az elmúlt években már több tanulmányban is összegeztük, lásd pl. Antal és $m$ tsai, 2015; Racsko és Herzog, 2015; Borbás, Herzog, Racsko, Szijártó \& Tóth, 2013, Herzog, Racsko és Kis-Tóth, 2014). Jelen írásunkban arra vállalkozunk, hogy a kutatási háttér rövid ismertetése után a tanórai táblagép-használatban érintett tanárok fókuszcsoportos vizsgálatának eredményeit ismertessük.

\section{Az újmédia-eszközök tanórai használatának bemutatása}

Az Eszterházy Károly Főiskola Gyakorló Iskolájában kezdetben a felső tagozatos tanulók bevonásával indultak el a táblagépes módszertani kísérletek (lásd az 5. ábrát).

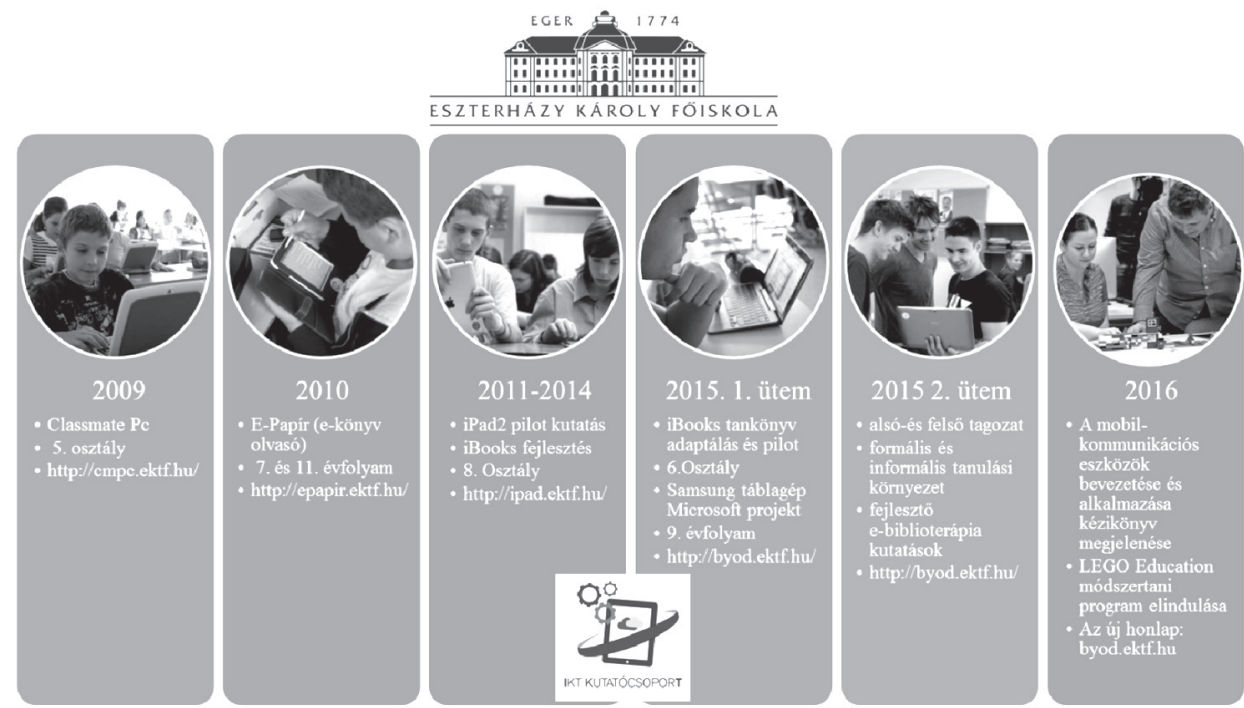

5. ábra. Az EKE Médiainformatika Intézetének közoktatásban zajlott kutatási portfóliója*

* A kutatásvezető mindegyik projektnél Kis-Tóth Lajos volt. A szakmai munkában az intézmény IKT Kutatócsoportjának tagjai vettek részt. http://byod.ektf.hu/rolunk/a-kutatocsport-tagjai 
A tabletek itt még elsősorban azzal a céllal kerültek alkalmazásra, hogy a pedagógusok megismerjék és módszertani kultúrájukba beépítsék az oktatást segítő alkalmazásokat. A 8. C osztályban a tanulók emellett a Mozaik Kiadó tankönyveit is használták - ekkor még statikus pdf-formátumban -, mely megoldással a hagyományos tankönyvek és az új platformon elérhető tartalmak szimbiózisát kívántuk megteremteni. A kutatás során azt is igyekeztünk felmérni, hogy a táblagépek köznevelésben történő beválása milyen feltételek mellett valósulhat meg, illetve mely tanulást segítő applikációval tehetnénk hatékonyabbá az oktatást. A vizsgálatot technikai és módszertani inkubációval is megtámogattuk, melynek keretében a projektbe bevont pedagógusok segítséget kaptak felmerülö problémáik megoldásához és szakmai fejlődésükhöz. A bevont tantárgyak a következők voltak: angol, biológia, földrajz, fizika, informatika, kémia, magyar irodalom, matematika, mozgóképkultúra és médiaismeret, történelem. A tanulók az eszközöket csak az iskolában használhatták, azok hazavitelére nem volt lehetőségük.

A kutatás következő fázisa a 2012/2013. 1. félévben kezdődött, amikor a korábbi statikus tankönyveket az interaktív iBooks tankönyvek váltották fel. Az oktatási eszközöket az egri föiskola Médiainformatika Intézetének fejlesztő csapata és a kutatásba bevont pedagógusok együtt dolgozták ki. A tankönyvek szakmai alapját a Nemzeti Tankönyvkiadó tananyagai alkották, ezeket a fejlesztők a pedagógusok instrukciói alapján mediatizálták, valamint az újonnan fejlesztett, tudásellenőrzést lehetővé tevő elemek (pl. interaktív tesztek) kidolgozását is elvégezték. A hagyományos, papír alapú tankönyveket a kísérlet idejére - a 8. D osztályban - a napi iskolai gyakorlatból mellőzték. A tapasztalatok azt mutatták, hogy az interaktív tankönyvek használata kibővítette a tanulási-tanítási lehetőségek tárházát, de sok esetben a platformfüggőség (a tankönyveket csak iPad eszközön lehetett megtekinteni) gátat is szabott a lehetőségeknek. A másik nehézséget az jelentette, hogy mivel az eszközt a diákok nem vihették haza, így az otthoni felkészülés során nem tudták igénybe venni az interaktív tankönyv nyújtotta lehetőségeket. ${ }^{7}$

A 2013/2014-es tanévben a táblagépek és az interaktív tananyagok alkalmazásának egy kibővített koncepciója indult el, amelynek keretében az 1., 3., 6. és 9. évfolyam egy-egy osztálya használt tabletet. A 9. osztályban a tanulók Samsung táblagépeket használtak, a többi osztályban pedig iPad2 eszköz állt a diákok rendelkezésére. Az 1. osztályos tanulók esetében a projekt kísérleti jellege úgy értendő, hogy mivel az első osztályos tanulók esetében kiemelten fontos az írástanulás során a finommotoros mozgások elsajátítása, ezért ebben a korosztályban inkább csak gyakorlásra vették igénybe az eszközt. A 3. osztály esetében saját fejlesztésü munkafüzet készült (éRTEm munkafüzet), amellyel a gyerekek szövegértés gyakorlását és fejlesztését segítették. A munkafüzet interaktív formában tartalmaz feladatokat, illetve hangoskönyveket a hallás utáni szövegértés gyakoroltatására. A 6. osztály számára is hasonló tartalommal készült egy saját fejlesztésủ munkafüzet, de a szaktárgyi érintettség miatt már a természettudományos területek kerültek a fejlesztés fókuszába.

Amint az a fenti táblázat adataiból is leolvasható, az EKF Gyakorló Iskolájában az elmúlt években egyre több tanulói csoportban alkalmazták a táblagépeket. 


\section{Az alkalmazott módszer jellemzése}

Az elmúlt években az Eszterházy Károly Főiskola Gyakorlóiskolájában a táblagépes módszertani kísérlet során számos kvalitatív és kvantitatív mérés zajlott (lásd 2. táblázat).

2. táblázat. A táblagépes iskolakisérletek során vizsgált területek és alkalmazott módszerek

\begin{tabular}{|l|l|}
\hline Vizsgált terület & Mérési módszer \\
\hline tanulói teljesítmény változása & naplómásolatok statisztikai elemzése \\
\hline szülői attitüdvizsgálat & kérdőíves vizsgálat \\
\hline tanulói attitüdmérés & kérdőíves vizsgálat \\
\hline tanórai módszerek vizsgálat & videós interakcióelemzés \\
\hline tanári vélemények, attitüdök mérése & fókuszcsoportos interjú és tartalomelemzés \\
\hline
\end{tabular}

A kutatások közül jelen esetben a tanári fókuszcsoportos interjú eredményeit mutatjuk be.

\section{Az adatfelvétel körülményei. A fókuszcsoportos kutatás struktúrája}

A fókuszcsoportos vizsgálat során a következő kérdésekre kerestünk válaszokat: (1) mennyiben tartják fontosnak, hogy a tanárok és a tanulók is magas szintü digitális írástudással rendelkezzenek; (2) a tanárok hogyan jellemzik a pedagógiai kísérletben részt vevők - a tanárok és a tanulók - újmédia használatát; (3) az oktatási folyamatban a táblagépek mely funkcióit és alkalmazásait vették leginkább igénybe; (4) az IKT-eszközök hatására változott-e a módszertanuk, (5) hogyan képzelik el a jövő iskoláját, oktatási színtereit? (lásd 6. ábra).

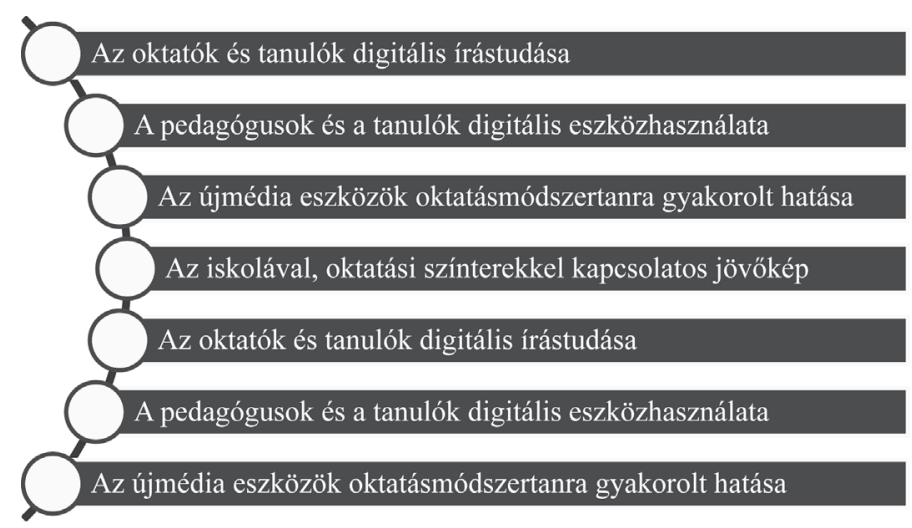

6. ábra. A méróeszköz bemutatása, az interjú-prokotoll 


\section{Mintavétel}

A strukturált interjú - előre kidolgozott kérdéssor - segítségével lefolytatott fókuszcsoporton kilenc gyakorlóiskolai oktató vett részt. A mintavétel során az elméleti mintát vettük figyelembe (Sántha, 2006, old.: 76), amely a kvalitatív vizsgálatoknál a statisztikai mintához képest inkább elfogadott.

A mintaválasztáskor a homogén stratégiát alkalmaztuk (Parton, 1990, idézi Sántha, 2006), mivel a csoportbeszélgetésben részt vevők mindegyike legalább két éve csatlakozott az iPades iskolai kísérlethez, és kíváncsiak voltunk arra, mennyiben hasonló vagy eltérő tapasztalatok birtokába jutottak. A minta további jellemzéséhez tartozik, hogy a kilenc oktató közül két fő volt alsó tagozatos tanítónő, három tanár a felső tagozatos, míg további négy kolléga a gimnáziumi osztályokkal foglalkozik.

A megjelentek létszáma alapján a gyakorlóiskola oktatási folyamataiban táblagépeket használó pedagógusok reprezentatív mintáját sikerült biztosítani. A minta jellemzését kiegészíthetjük még azzal, hogy a felsőbb osztályokban az oktatók a magyar nyelv és irodalom, a rajz és az angol nyelvi órákon, illetve jellemzően a természettudományos tárgyaknál - a fizika, kémia, matematika, földrajz és a természetismeret órákon - használták a táblagépeket.

A több mint másfél órás megbeszélés verbális és nonverbális folyamatait, kommunikációs helyzeteit két kamerával rögzítettük, mely felvételek a tartalmi elemzésen kívül egyéb kvantitatív vizsgálatok lefolytatására is alkalmasak lesznek.

Terveink szerint a digitális tényanyagot, azaz a fókuszcsoportos interjú szövegkönyvét, illetve a módszertani iskolakísérlet online, zárt fórumában tett bejegyzések elemzését a MaxQda szövegelemző szoftverrel, induktív kódolással is elvégezzük. Ez azt jelenti, hogy a kódolás kategóriáit az elemzés során hozzuk létre. A tanórafelvételek vizsgálatára videós interakcióelemzést alkalmazunk, ahol egy előre megalkotott kódolási sablonnal deduktív kódolást végzünk. A korábbi kutatásokban elsősorban a kvantitatív módszereket részesítettük elönyben, így a tanulók és a szülők kérdőíves kikérdezését, valamint a tanulók érdemjegyeinek statisztikai elemzését. Úgy véljük, hogy a módszertani trianguláció (Sántha, 2015), azaz a kvalitatatív és kvantitatív módszerek együttes alkalmazása hozzáadott értékkel bír az ilyen kutatások során is, illetve a rejtett összefüggések feltárására is alkalmas lehet.

\section{A fókuszcsoportos interjú eredményei}

A tanulmány folytatásában az eredményeket a fentebb megnevezett kutatási kérdések sorrendjében közöljük.

\section{Az oktatók és tanulók digitális írástudása}

A fókuszcsoportos megbeszélésen aziránt érdeklődtünk, hogy a kollégák milyen véleményt formálnak a 21. század infokommunikációs túlterheltségéről, az újmédia-eszközök osztálytermekben való megjelenéséröl, illetve a tanári és a tanulói digitális kompetenciával kapcsolatos társadalmi elvárásokról.

Tapasztalatunk szerint a pedagógusok egyetértenek abban, hogy a 21. század újmédiaalapú technológiáinak tanórai használatát egyre kevésbé lehet nélkülözni. A válaszadók szerint ugyanakkor nélkülözhetetlennek tartják a tanárok IKT-eszközökkel kapcsolatos szemléletváltását, a tanórák tartalmához jól illeszkedő módszertant és az előzetes felkészülést. Többen hangsúlyozták, hogy bár a pedagógusok maguk is rendelkeznek saját 
személyes használatú mobil eszközzel (pl. okostelefon, laptop, iPad), mégis szükségét látják annak, hogy több időt szánjanak IKT-kompetenciájuk fejlesztésére. Egybehangzóan állították, hogy az újmédia-technológiák oktatási folyamatba való bevonása rengeteg lehetőséget hordoz magában.

Magyartanár (45-50 éves): „Szerintem a tanulók tele vannak eszközökkel, az oktatás szempontjából azonban nem használják jól ezeket. Mi is rendelkezünk ezekkel, de igen erősen szükséges fejleszteni a saját IKT-kompetenciánkat, hogy pont abban tudjunk a

Tapasztalatunk szerint a pedagógusok egyetértenek abban, hogy a 21. század újmédiaalapú technológiáinak tanórai használatát egyre kevésbé lehet nélkülözni. A válaszadók szerint ugyanakkor nélkülözhetetlennek tartják a tanárok IKTeszközökkel kapcsolatos szemléletváltását, a tanórák tartalmához jól illeszkedô módszertant és az elózetes felkészülést. Többen hangsúlyozták, hogy bár a pedagógusok maguk is rendelkeznek saját személyes használatú mobil eszközzel ( $p l$. okostelefon, laptop, iPad), mégis szükségét látják annak, hogy több idót szánjanak IKTkompetenciájuk fejlesztésére. Egybehangzóan állitották, hogy az újmédia-technológiák oktatási folyamatba való bevonása rengeteg lehetôséget hordoz magában. diákoknak segíteni, hogy oktatási helyzetben is képesek legyenek hatékonyan alkalmazni ezeket."

Fizikatanár (50-55 éves): „...Sok lehetőség van a mobil eszközökben. A saját tantárgyamhoz számtalan olyan szoftvert és eljárást lehet az okostelefon vagy a táblagép segítségével letölteni, amelyek kiválóan alkalmazhatók a különböző mérésekkel kapcsolatban. Gondolok itt pl. olyan szoftverre, mint a hőkamera a hullámok tanításánál. Mivel majdnem minden tanuló rendelkezik ezzel a mobil eszközzel, ezt a technológiát kézenfekvő a tanórán alkalmazni, vagy az arra való felkészülésbe bevonni. Ilyen esetekben a diák legálisan használja a tanórán céltudatosan, az oktató irányítása mellett - a különböző mobil applikációkat vagy akár a tabletet."

A fókuszcsoport résztvevői közül többen is szakvezetők, illetve szaktanácsadók, így sokféle tapasztalattal rendelkeznek a tanár-, illetve a különböző tanári továbbképzésre vállalkozó kollégákkal kapcsolatban. A hozzászólásokból kiderült: igen gyakran találkoznak „médiapesszimista” pályatársakkal, akik valami oknál fogva elutasítják az újmédia-eszközök tanórai használatát.

Angol szakos tanár, szaktanácsadó (45-50 éves): „Szaktanácsadóként országos kitekintést sikerült szereznem arról, hogy még mindig mennyire jelentős azon kollégák száma, akik ellenállnak a mobil eszközök, az IKT-technológiák tanórai alkalmazásával kapcsolatban. Vannak olyanok is, akik ki is mondják, hogy azért se, vagy azt, hogy majd én megmutatom, hogy anélkül is tudok hatékony pedagógus lenni. Sokan mondják, hogy ez csak időpocsékolás, nem fogom az időmet az IKT-eszközök összeszerelésével eltölteni. Mert mi van akkor, ha nem elég erős az internetkapcsolat? Mi van, ha leáll az internetes rendszer? Tehát a bonyolultságát, bizonytalanságát látják a dolgoknak. Egy szükséges rossznak tartják a technikát. Feltételezhetően voltak ezeknek a véleményeknek előzményeik - mondjuk a próbálkozásokat kudarcélmények kísérték -, tehát nem csak ő tehet erről a hozzáállásról." 
Kémia- és fizikatanár, szakvezető (45-50 éves): „A mesterképzésben részt vevő kollégáktól többször is hallottuk a következő véleményt: nagyon jó, ha itt a gyakorlóiskolában be tudok vinni a kémialaborba 30 laptopot is, vagy a számítógéphez kamerát tudok csatlakoztatni, de a saját iskolájában ez az infrastruktúra nem biztosított. Neki olyan eszközöket és módszereket mutassak, amelyekkel egy tanyasi, vidéki, gyengén felszerelt oktatási intézményben - kevésbé motivált gyerekekkel - is hatékonyan tud dolgozni a természettudományos órákon. A továbbképzésen részt vevő pedagógusok különböző életkora is lényeges, mert az idősebb kollégák számára a projektor és a laptop megfelelő összeillesztése, illetve egy prezentáció, vagy a tervezetek elektronikus formában való elkészítése is igen gyakran kihívást jelent."

A digitális írástudásról általánosnak mondható az a vélemény, hogy a 21. század egyik legfontosabb kulcskompetenciájának számít, mely készségeket és ismereteket az iskolában kell a gyerekeknek elsajátítaniuk. Az ehhez tartozó eszközparkot minden közoktatási intézményben biztosítani szükséges azért, hogy a tanulók digitális felkészültsége között ne legyenek különbségek.

Rajztanár (55-60 éves): „Középiskolai tanárként úgy gondolom, hogy a tanulóinkat kötelesek vagyunk felkészíteni arra, hogy a felsőoktatásban alapkészségnek számít a magas szintű digitális kompetencia, a digitális eszközök rendeltetésszerü használata. Ha ök úgy érettségiznek le, hogy az közoktatásban nem szerzik meg az ide vonatkozó tapasztalataikat, akkor az egyetemeken óriási lépéshátrányba kerülnek."

Angol szakos tanár, szaktanácsadó (45-50 éves): „Nem csupán a felsőoktatásban, hanem a munkaerőpiacon is alapkövetelménynek számít a digitális kompetencia. Azzal is tisztában kell lennünk, hogy nem minden tanulónak biztosított az otthonában az iPad vagy az okostelefon. Nem mutogathatunk a gyerekek szülői hátterére. Alapvető elvárás szerintem, hogy a tanuló az iskolában, oktatási környezetben találkozzon ezekkel az eszközökkel."

\section{A pedagógusok és a tanulók digitális eszközhasználata}

A megbeszélésen a kollégák határozottan különválasztották a tanórai és tanórán kívüli médiahasználatot. A jelenlévők egyetértettek abban, hogy a tanórákra történő felkészülést (adatgyűjtést, óravázlatok írását, témazárók és dolgozatok írásbeli előkészítését stb.) elektronikus felületeken teszik meg. Egyre többen élnek a Facebook közösségi oldal adta alkalmazási lehetőségekkel is: hallottunk példát arra, miként lehet a tanórán elhangzott ismereteket a közösségi oldalra feltöltött feladatokkal és irányzott kérdésekkel megtámogatni, illetve arra is, hogy osztályok, kémia és fizika fakultációra járó diákok - a tanár csoporttagsága mellett - miként formálódnak zárt, összetartó, sajátságos szabályok szerint müködő közösséggé. A tanulmány folytatásában a fókuszcsoportos beszélgetésből azokat a szövegrészleteket emeljük ki, amelyekből kiderül, hogy miként jellemezhető a gyakorlóiskolai tanárok és a tanulók újmédia-használata, illetve arra a kérdésre is választ kapunk, hogy az iskolakísérlet oktatási folyamatában a pedagógusok a táblagépek mely funkcióit és alkalmazásait vették leginkább igénybe.

Matematikatanár (50-55 éves): „Az órákra való egyéni felkészülésemet elektronikus felületen folytatom, értve ezen pl. a tanórai szemléltetéseket, és az órai vázlatok összeállítását is. Nekem papíros vázlatom évek óta nincs, átálltam a digitális felkészülésre."

Fizikatanár (50-55 éves): „A felkészülésnél óriási mértékben támaszkodom az elektronikus felületekre és eszközökre. Gyakorlatilag szinte teljes egészében innen keresek adatokat."

Természetismeret szakos tanár (30-35 éves): „Tanulóim körében most kezd szokássá válni, hogy fizika-kémia címen közös Facebook csoportot alakítanak, és a tanórán 
készített felvételeket vagy a lejegyzetelt óravázlatokat feltöltik erre a tárhelyre. Ennek olyan előnye is van, hogy aki valamilyen ok miatt hiányzik az óráról, az sem marad ki az óra menetéből, vagy éppen a kísérletek látványából, így ő is szerezhet vizuális tapasztalatokat."

Kémia- és fizikatanár, szakvezetö (45-50 éves): „A Facebook közösségi oldal jól müködhet az iskolai tanulási folyamatok támogatásaként is. A tanulóim kialakítottak egy olyan kémiai Facebook- csoportot, amelynek én is tagja vagyok, és szívesen is fogadják a hozzászólásaimat, a hálózati jelenlétemet. Előfordul, hogy ha pl. az este folyamán találok olyan mobil alkalmazást, amit jó lenne a következő a tanórán használni, és ennek linkjét átküldöm nekik, akkor tapasztalatom szerint mindannyian szívesen megkeresik, letöltik és így várnak rám. Ez is az együttmüködésüket és a nyitottságukat igazolja számomra."

A mobil eszközök tanórai használata tantárgyanként, tananyagonként és tanulói csoportonként is változó képet mutat. A megbeszélésen hallottak alapján helytálló az a kijelentés, miszerint a gyakorlóiskolai oktatók - bár eltérő gyakorisággal, de - szívesen veszik igénybe a digitális felületeket. Felmerült ugyanakkor a kollégák részéről, hogy ellentmondás van az iskolai házirend és a mobil eszközök oktatási intézményen belüli használata között. A szabályzatot valójában idejétmúltnak tartják, és érdemesnek tartanák a dokumentumot az életszerủ szituációhoz igazítani.

Fizikatanár (50-55 éves): „Az óra jellegétől függ a tabletek használata. Van olyan eset, amikor sokat, de adódik, amikor más eszközök használatára szorítkozunk. De még így is azt gondolom, hogy a fizika órák több mint 50\%-ában használjuk a digitális eszközöket."

Matematikatanár (50-55 éves): „Teljesen attól teszem függővé az eszközhasználatot, hogy milyen tananyaggal foglalkozom. Minden esetben mérlegelem, hogy az adott témához kapcsolódóan mennyire tudom a mobil eszközöket hatékonyan alkalmazni. Számonkéréseknél pl. a teszteket iPaden íratom meg a hetedikes gyerekekkel (a kísérleti osztály minden tagja kapott táblagépet)."

Kémia- és fizikatanár, szakvezető (45-50 éves): „A tabletek, IKT-eszközök tanórai használata nagyon sok mindentől függ. Attól is, hogy milyen tárgyról, milyen korcsoportról vagy milyen tananyagtartalomról van szó. A tanulóknak engedem használni a mobiltelefonok számológép funkcióját. A kísérletek megörökítését is lehetővé teszem - az órán a diákok készíthetnek fotót és video- felvételeket is. A tanárjelölt kollégákat ugyanakkor mindig arra biztatom, hogy ha prezentációval szeretné megtámogatni az óráját, akkor mindig legyen egy »B« verziója. Nem szabad csupán az elektronikában bízni, mert a technika ördöge bármikor képes megtréfálni az embert. Nem vagyok híve a kizárólagos, állandó prezentálásnak, mert pl. szerves kémiából a kísérletek során szerzett személyes tapasztalatokból lehet a legtöbbet tanulni."

Fizikatanár (50-55 éves): „Fizikaórán jellemzően mérőeszközként használjuk az IKT-eszközöket. A megfelelő interface-eken, szondákon keresztül egészen új dimenzióit ismerhetik meg a gyerekek ezeknek a készülékeknek. A megfelelő mérési eljárásokhoz illesztett szoftverek most már ingyenesen letölthetők, utána már csak a kapcsolódó szenzort kell beszerezni hozzá, kiegészítve például olyan azonnali kiértékeléssel, mint a grafikonos megjelenítés. Nyilván nem a megjelenítés az elsődleges cél, hanem a kapott adatok további összehasonlítása, illetve a folyamat fejlesztése."

Kémia- és fizikatanár, szakvezető (45-50 éves): „Én a mobil eszközök tanórai használatának ellentmondására is felhívnám a figyelmet. Mivel a gyakorlóiskolában a házirend tiltja a tanulóknak a mobiltelefon tanórai használatát, akkor kettősséggel találjuk szembe magunkat. Egyrészt amikor a gyerek nem irányítottan veszi elő a személyes tulajdonban lévő újmédia-eszközét, és rászólok, hogy tegye azt el, akkor eleget teszek az intézményben elöírt kötelmeknek. Amikor meg azt mondom neki, hogy vegyük elö, és a letöltött periódusos rendszerből nézzük meg az adott elemhez tartozó adatokat, akkor pedig ellene megyek az egésznek. A gyerek jogosan teszi fel a kérdést: mikor szabad és mikor nem 
az eszközt használni? Szemléletváltásra tehát nem csupán a pedagógus egyéni szintjén van szükség, hanem az intézményvezetés szintjén is, hogy az ellentmondások megszünjenek."

Rajztanár (55-60 éves): „Vizuális kultúrát tanítok, ahol elsőre talán nem egyértelmü az IKT-eszközök használata. Tanórán szemléltetés céljával napi szinten használatban vannak ezek az eszközök. A középiskolai osztályokban müvészettörténetet is tanulnak a diákok. A világhálóról - fantasztikus technikai minőségben - óriási képanyag érhető el, ami nagyban segíti a tanulók ismeretszerzését. Használata kiterjed továbbá a tankönyvi anyagok kiegészítésére, illetve megvalósult a számonkérés digitalizált módja is."

Angol szakos tanár, szaktanácsadó (45-50 éves): „Az újmédia-eszközök tanórai használatának abban látom a legtöbb hozadékát, hogy egyrészt fantasztikus motivációs lehetőséget ad a különböző nyelvi készségek fejlesztésére, másrészt a nyelvtanulás valós funkcióját segíti. Mert akárhogy is nézzük, az iskolai nyelvtanítás mindig csak egy mesterséges légkörben, közegben zajlik. A folyamat nem természetes, hiszen adott a tanórai szituáció. Viszont ha a gyerek egy angol nyelvü honlapot kap tanulmányozásra, és a megadott szempont alapján kell kikeresnie dolgokat, akkor az már nem preparált vagy könnyített szöveg, hanem egy igazi dolog, és a nyelv valódi funkcióját alkalmazza. Amennyiben megtalálja a keresett információkat, akkor nagyobb lesz a tanuló sikerélménye, ugyanakkor azt is magabiztosan kijelentheti, hogy arra használta a nyelvet, amire való, hogy megértse azt, amit oda leírtak. Az ilyen módszereket nagyon szeretik a gyerekek. Az eszköznek köszönhetően a valódi nyelv igazán közel kerül a tanulókhoz.”

Tanitónő (50-55 éves): „Osztályfönökként matematikát, környezetismeretet, magyar nyelvet és irodalmat is tanítok, de föként a matematikai programok adta lehetőségeket tudtuk kihasználni. Elég régóta, tehát a 2013/2014-es tanévtől használjuk az iPadet a tanórákon, akkor elsősök voltak a tanítványaim. Nagyon hasznos programokat találtunk a betüpárok tanításához, illetve a kézügyesség fejlesztéséhez is. A tanulóim játékként élik meg az ilyesfajta gyakorlást, egészen más egy matematikai müveletsort a munkafüzetben írásban megoldani, mint egy digitális eszközön. Otthon, amikor elmesélik, hogy mi volt pl. a matematikaórán, akkor leginkább azt hallják a szülők, hogy játszottunk. Pedig az iPaden is ugyanolyan feladatokat oldunk meg, mint a munkafüzetben, mégis a digitális eszközhasználatban sokkal több az örömforrás."

A tanulók iskolai digitális eszközhasználatáról is szívesen nyilatkoztak a fókuszcsoport tagjai. Általánosságban úgy vélik, hogy a diákok többsége sokoldalúan és gyakorlottan kezeli az újmédia-eszközöket és -alkalmazásokat. Amennyiben a különböző tanórákon számukra ismeretlen felhasználói felületet sikerül mutatni, akkor a fiatalok nyitottak és érdeklődők az új lehetőségek iránt.

Magyar szakos tanár (45-50 éves): „A gyerekek leginkább szórakozási céllal veszik kezükbe az új média technológiáit, és csak második vagy harmadik helyre szorul az iskolai alkalmazás. Nekünk a technológia és az oktatás közti rést kellene megtalálni és ügyesen tartalommal megtölteni."

Kémia- és fizikatanár, szakvezető (45-50 éves): „Én a Prezi alkalmazást szégyenszemre nem tudom még használni. De az egyik középiskolás diákom fizikaórára olyan tartalmas prezentációt készített ezzel, hogy azt óra végén feltétlenül újra meg kellett néznem az iPaden. Ha engedjük őket, akkor nagyon kreatívak tudnak lenni."

Angol szakos tanár, szaktanácsadó (45-50 éves): „Úgy gondolom, hogy a gyerekek önmaguktól a játékon és a chatelésen kívül nem hiszem, hogy másra is használnák a gépet. Ha itt az iskolában nem szoktatnánk őket arra rá, hogy egy csomó minden mást is lehet vele csinálni, pl. ismeretszerzésre, forrásgyüjtésre, különböző alkalmazási formák letöltésére, és sorolhatnám ezeket, ezt sem önmaguktól, sem pedig a család többi tagjától nem tudnák elsajátítani, nem kapnának ehhez segítséget. Elég valószerütlennek tartom, hogy a szülö megkérje arra a gyerekét, hogy kislányom/kisfiam, készíts már nekem egy 
ppt-t. Ha jobban belegondolunk, akkor ezeket mind tölünk tanulják meg a gyerekek. Jó dolog azt megélni a tanulókkal, amikor rákapnak egy dologra. Ilyen volt nálunk angolórán a képregényszerkesztő alkalmazás, amire teljesen véletlenül bukkantam rá. Először csak egy kis oktató demót mutattam meg a gyerekeknek, amit azzal a szándékkal készítettek a fejlesztők, hogy az alkalmazás lehetőségeit felvázolják az érdeklődőknek. Miután felvillantottam nekik ezt a kisfilmet, még szerettem volna néhány rövid magyarázattal is szolgálni, néhány apróságot helyére tenni, de a gyerekeknek ezt már nem volt türelmük kivárni. Azonnal elkezdtek munkálkodni, és 3-5 perc alatt olyan anyagok születtek, amelyekre legmerészebb álmaimban sem gondoltam volna. A tanulók tehát nagyon fogékonyak, nagyon produktívak, és ezek az új alkalmazások nagyon hasznos segédanyagokká válhatnak. De önmagától a diák nem kezdene bele egy ilyen programba, ehhez nekünk kell felkelteni az érdeklődését, és kinyitni számára az új média világát."

Tanitónő (55-60 éves): „A gyerekek az iskolában nagyon várják azokat az órákat, ahol a tabletekkel dolgozhatnak. Mindig érdeklődnek aziránt, hogy mikor fogunk olyan tananyaghoz érni, amihez használhatjuk majd az új média technológiát. "

Tanitónő (55-60 éves): „A kisiskolások a tankönyveket nem tudják olyan rendben tartani a padban, mint mondjuk az újmédia-eszközöket. A gyerekek az óra elején kiveszik a tanteremben elhelyezett bőröndből az elektronikus eszközöket, az óra végén pedig önállóan a helyére teszik azokat. Látni rajtuk, hogy sokkal kevesebb a gondjuk ezzel.”

\section{Az újmédia-eszközök oktatásmódszertanra gyakorolt hatása}

Izgalmas kérdés, hogy a tanórákon használt újmédia-eszközök és alkalmazások befolyásolják-e valamilyen módon a tantermi oktatásszervezési eljárásokat. A megbeszélésen több olyan gyakorlatias példát is hallhattunk, ami azt igazolta, a pedagógusok ezen a téren is készek a szemléletváltásra, az új helyzetek, osztálytermi szituációk felvállalására.

Kémia- és fizikatanár, szakvezető (45-50 éves): „Az eszközhasználat kapcsán szerintem tudomásul kell venni, hogy az ún. poroszos tanórai kötelmek maguktól is meg fognak szünni, az új módszerek és eljárások iránt nyitottnak kell lenni. Ez független az életkortól vagy a tantárgyaktól is - ezeket az eszközöket be kell vezetni az oktatásba."

Természetismeret tanár (30-35 éves): „Élmény látni, hogy a gyerekek milyen természetességgel nyúlnak ezekhez az eszközökhöz, milyen oldottan használják. A földrajzórákon egyre nagyobb mértékben támaszkodunk erre az infrastruktúrára. A földrajzkönyvet már nem kérem, hogy elhozzák az órákra, mert az OFFI honlapjáról az új könyvek digitálisan is elérhetők. Mondanom sem kell, hogy a tanulók mennyire örülnek annak, hogy egy könyvvel kevesebbet kell a táskájukban hordaniuk. "

Fizikatanár (50-55 éves): „Figyelni kell arra, hogy a tanuló az órán tényleg arra használja az eszközt, amire mi szeretnénk. Jelenleg még nem megoldott, hogy állandó visszajelzésünk legyen arról, tényleg együtt halad-e velünk a diák. Ezért érdemes csoportmunkában kiadni feladatokat, ahol az ott elért eredményekröl közösen számolnak be a gyerekek. Így konkrét visszacsatolással rendelkezünk a diákok előmeneteléről.”

Magyar szakos tanár (45-50 éves): „Nekem most új szerelmem van, a Redmenta*. Az alkalmazásra egy kolléganőm hívta fel a figyelmemet, és a kötelező olvasmány olvasottsági szintjét tudom majd ezzel mérni. Ezzel a programmal állítottam össze a 8. osztályos tanulók tesztjét, és bevallom, nagyon izgulok, hogy miként fog működni a dolog. Talán jobban izgat engem, mint a diákokat."

* Redmenta: az intelligens oktatási asszisztens, https://redmenta.com/ 
Angol szakos tanár, szaktanácsadó (45-50 éves): „Az órának nem lehet kizárólagos célja az eszközhasználat, és ez igaz az újmédia-eszközökre is. Egyre fontosabb a következetesség, tudnunk kell, hogy milyen esetben élünk az iPaddel vagy mobiltelefonos alkalmazással, és melyek azok a célok, amikor egyáltalán nincs helye az oktatási folyamatban ezeknek az eszközöknek. Nagyon rossz példákat is láttam már nyelvórákon. A gyerekek nyilván nagyon szeretik az interaktív tananyagokat, amikor tevőlegesen is részt vehetnek az óra menetében (pl. az interaktív táblánál kiválasztani, majd a helyére húzni a megfelelő kifejezéseket a virtuális táblánál). Izgalmas az is, amikor az ellenőrzés valamilyen szavazórendszer segítségével történik. De ott van a probléma, ha a tanuló egy idegen nyelvi órán - bár valóban elvégzi a feladatokat - ki sem nyitja a száját, a verbális kommunikációnak nyomát sem látjuk. A kolléga hiába vonultatott fel csodálatos IKT-arzenált, de arra már lehetőséget sem adott, hogy a gyerek hangosan kiejtse az angol kifejezést."

Természetismeret tanár (30-35 éves): „Ne tagadjuk le, hogy a gyerekektől is rengeteget lehet tanulni. Többször is adódott arra példa, hogy nem voltam tisztában egy-egy alkalmazás használatával, és a gyerekek rögtön készek voltak megmutatni nekem. Tölük tanultam meg a Google Drive alkalmazás használatát is. Ök mutatták meg, hogy a program tartalommegosztás lehetőségével miként váltható le a csoportos e-mail küldés."

Fizikatanár (50-55 éves): „A technológia fejlődésével annyi impulzus ér bennünket, hogy az alkalmazásokhoz igazítva mindig megújul a módszertárunk is. Nyilván sok esetben ez nem tudatosan megy végbe, mert a fejlődés - az újabb és újabb lehetőségekre válaszolva - szép lassan egymásra rakódva történik meg bennünk. Mindig megpróbálom először a lehetőségek körét kipróbálni, majd ezután építem be a saját módszertanomba, az óra tartalmi részének a megvalósításába. Lemaradni a technológia fejlődésétől vétek. Ezt biztosan állíthatom."

Tanitónő (50-55 éves): „Most egy kicsit felemás helyzetben vagyok, mert első osztályban tanítok. Írni-olvasni még nem tudnak a gyerekek, és november elején kapták kezükbe a táblagépeket. Rendkívül jók a tapasztalataim, sokkal rosszabbra számítottam. Nagyon jól lehet őket motiválni, de a fegyelmezésre is sok időt kell szánnom. Folyamatosan ezzel játszanának, ezért szükséges sokszor elmondanom, hogy csak azután lehet, ha még most rám figyelnek, és csak utána vehetik elő az eszközt. A negyedik osztályos tanulóimmal tavaly már eljutottunk odáig, hogy remek ppt-ket csináltak. Aki vállalkozott tanórán kívüli feladatok megoldására, azok hazavihették a táblagépeket, és cserébe nagyon kreatív, izgalmas dolgokkal jutalmaztak meg bennünket."

\section{Az iskolával, oktatási színterekkel kapcsolatos jövökép}

Az elmúlt évek iPades iskolakísérleteiben részt vevő gyakorlóiskolai oktatók a mindennapi oktatómunkájuk során nagy gyakorlatra tettek szert az újmédia-eszközök tanórai alkalmazásában. Tapasztalataikkal tehát nagyban tudják segíteni nem csupán a tantestület tagjainak hasonló irányú törekvéseit, hanem hasznos javaslatokkal képesek irányítani a tanár- és a különböző pedagógus továbbképzésben részt vevő kollégák IKT-val kapcsolatos ismereteinek gyarapítását is. A fókuszcsoportos megbeszélés végén kíváncsiak voltunk arra, milyen jellemzőkkel írnák le a jövő iskoláját? A válaszok közül kiválasztottunk néhányat.

Fizikatanár (50-55 éves): „A tanulási környezet az elmúlt évtizedekben olyan sokat változott, hogy nagyon nehezen merném megjósolni, hogy mi lesz kb. 20 év múlva az iskolában, mi és hogyan változik akkorra. Biztosan nem elkerülhető, hogy az információs rendszer még jobban, még adekvátabb részévé váljon oktatási környezetünknek." 
Magyar szakos tanár (45-50 éves): „Jó lenne, ha a jövő iskolájában az online terek offline kiterjesztése kedvesebb, hangulatosabb belső tereket eredményezne. Egy-egy tanórán kis létszámú gyerekcsoportban, szép, színes átjárható terekben foglalkozhatnánk a tanulókkal. Úgy képzelem, hogy a jövőbeli iskolai környezet kedvesebb, otthonosabb, élhetőbb világot jelenít majd meg. Egy ilyen környezetben megvalósulna a kellö egyensúly az online és az offline világok között. Nem gondolom, hogy online fogunk tanítani, mert egy ilyen környezetbe a tanulók és a tanárok is szívesen fognak bejárni."

Angol szakos tanár (40-45 éves): „Egy nyelvórán mi is beszélgettünk a gyerekekkel a jövő iskolája témáról. Találtam egy filmes bejátszást egy hipermodern iskoláról, ahol hatalmas fal méretű kivetítőn egy tanár ide-oda húzogatta a látványos elemeket, ha megnyomott egy gombot, akkor a gyerekek elé automatikusan feljött egy asztal, stb. Az óra menetében elhangzott az a kérdés is, hogy a jövő iskolájában szükség van-e egyáltalán a tanárra, vagy megoldanak mindent a gépek, a robotok? Elözetesen úgy gondoltam, a gyerekek könnyen lemondanak a pedagógus jelenlétéről. A tapasztaltak jóleső érzéssel töltöttek el. A tanulók ugyanis egyértelműen kijelentették, hogy a tanárra márpedig szükség van. Szükségük van arra, hogy olyan tanárszemélyiség álljon előttük, akit tisztelni tudnak a tudásáért, aki többet tud náluk, aki segítséget nyújt abban, hogy mit, hogyan kell megtanulniuk. A gyerekek ezt nem a gépektől akarják hallani, nem akarnak bennünket lecserélni."

\section{Összegzés}

Jelen tanulmányban összefoglaltuk azokat a tapasztalatokat, amelyeket az elektronikus tanulási környezet kapcsán a pedagógusok elmondtak. Úgy gondoljuk, hogy az egri innováció sikere számos tényezőtől függ, amelyek egyben a fenntarthatóságot is biztosítják. Ezek között hangsúlyos a pedagógusok attitüdje, felkészültségük, illetve az intézmény vezetésének és az egész tantestületnek a támogató hozzáállása.

A fenntarthatósághoz szükség van anyagi erőforrásokra, hiszen az eszközök avulása, cseréje és a stabil vezeték nélküli internethálózat folyamatos korszerüsítése kulcskérdés. Ha nem csak az infrastruktúrát nézzük, a folyamatos módszertani és technológiai inkubációra, amely a személyes találkozástól, a weboldalon keresztüli zárt fórumüzenet-váltásokig sok formában megtörténhet. Úgy tapasztaljuk, hogy ennek a módszernek a segítségnyújtás és a tapasztalatcsere révén olyan hozzáadott értéke van, amely átlendíti a pedagógusokat az esetleges nehézségeken, és tovább ösztönzi öket. Ezt támasztja alá, hogy számos IKT-eszköz bevezetésével kapcsolatos projektnél a top-down, azaz a felülről szerveződő megvalósítás volt a jellemző, amely elsőként (több esetben kizárólagosan) az infrastruktúra kiépítését jelentette, önmagában kevés (Molnár, 2011).

A másik kulcskérdés az új módszerek és módszertani modellek implementációja, amely esetünkben a fejlesztő e-biblioterápia* formájában, valamint a LEGO-termékek és az IKT-eszközük új lehetőségeinek megtalálásában tárgyiasul.

A további lényegi elem a tartalom, ${ }^{* *}$ amely a tanítási célok és a hatékonyabb tudáselsajátítás érdekében az okoseszközök lehetőségeit kihasználja. Emellett olyan kézi-

* Bővebben a téma kutatójának írásából: Gulyás Enikő: E-biblioterápia, egy új módszer az általános iskolai gyakorlatban. Iskolakultúra. 2015. 1. sz. http://www.iskolakultura.hu/ikultura-folyoirat/documents/2015/01/08. pdf

** A tartalomfejlesztés megvalósulhat saját erőből, amely a törzsanyag megírásán túl a médiaelemek fejlesztését és a komplett kivitelezést jelenti, amely meglehetősen erőforrás-igényes. Egerben két ilyen fejlesztés valósult meg az elmúlt években (Értem-munkafüzet és Nemzeti Tankönyvkiadó tankönyveinek iBooks formátumban történő fejlesztése). 
könyvek, segédanyagok rendelkezésre állása, amely az új tanulási környezet lehetőségeit mutatja be.*

Összességében azt mondhatjuk, fókuszcsoportos vizsgálatunk legfőbb eredményének azt tartjuk, hogy a digitális írástudással kapcsolatban - amely a 21. század egyik legfontosabb kulcskompetenciájának számít - a jelen lévő kollégák mindegyike részéről igazolni tudtuk azt a magas szintű elköteleződést, amely nem csupán az egész életen át tartó tanulás, hanem a tudáson alapuló társadalom megteremtésének is az egyik alapfeltétele. Az irányított beszélgetés további hozadékát az jelentheti, hogy az újmédia-eszközök tanórai alkalmazásával kapcsolatban egy sor olyan életszerü iskolai helyzetről, gyakorlatról hallottunk, amelyek további elemzése segítséget adhat a technológiák közoktatásban történő hatékonyabb alkalmazásához. Ennek keretében a jövőben tervezzük többek között a rögzített tanórák (kb. 100 órafelvétel) videós interakció-elemzéssel történö, különböző szempontú vizsgálatát, valamint a tanulók által készített munkák multikódolt elemzését.

\section{Irodalomjegyzék}

Antal P., Borbás L., Gulyás E., Herzog C., Kárpáti A., Kis-Tóth L. és Racsko R. (2015): Tudásteremtés az új tanulási környezetben. a táblagépek beválásvizsgálata a köznevelés hazai gyakorlatában. In: A. Verók: A humán teljesitménytechnológia. Líceumi Paletta (pályázati különszám). Líceum Kiadó, Eger. 27-37

Bedő, A. és Schlotter, J. (2008): Az interaktiv tábla. Müszaki Kiadó, Budapest.

Bonk, C. J. és Zhang, K. (2008). Empowering Online Learning: 100+ Activities for Reading , Reflecting, Displaying, and Doing. Jossey-Bass, San Francisco, CA.

Borbás L., Herzog C., Racsko R., Szíjártó I. és Tóth T. ( 2013). Médiatudatosság és médiaműveltség: összegző tanulmány. In: Bárdos J., Kis-Tóth L- és Racsko R.: Új kutatások a neveléstudományokban: Változó életformák, régi és új tanulási környezetek. Magyar Tudományos Akadémia Pedagógiai Tudományos Bizottság-Líceum Kiadó, Eger. 9-23.

Brecko, B. N., Kampylis, P. és Punie, Y. (2014): Mainstreaming ICT-enabled Innovation in Education and Training in Europe: Policy actions for sustainability, scalability and impact at system level. JRC. Scientific and Policy Reports. Seville: JRCIPTS. doi:10.2788/5208, http://ipts.jrc.ec.europa.eu/ publications/pub.cfm?id=6361.

Chatti, M. A., Agustiawan, M. R., Jarke, M. és Specht, M. (2012). Toward a personal learning environment framework. Design, implementation, and evaluation of virtual learning environments. IGI Global. DOI: 10.4018/978-1-4666-1770-4.ch003

Chyung, S. Y. (2008): Foundations of instructional and performance technology. Amherst, MA, HRD Press.

Dabbagh, N. és Kitsantas, A. (2012): Personal Learning Environments, social media, and selfregulated learning: A natural formula for connecting formal and informal learning. The Internet and Higher Education, 15 (1), 3-8. DOI: 10.1016/j. iheduc.2011.06.002

Herzog, C., Racsko, R. és Kis-Tóth, L. (2014): Tudásteremtés új tanulási környezetben: egy táblagépes kísérlet tanulságai (absztrakt). In: Göncziné K. K. és Kis-Tóth L.: Agria Média 2014 információtechnikai és oktatástechnológiai Konferencia és Kiállitás. Program és összefoglalók. Líceum Kiadó, Eger. 54-55.

Kis-Tóth L. (2009): A tanári tevékenység IKT elemei. Tézisek. Habilitációs értekezés. 137.

Kis-Tóth L. (2013): Az oktatás támogatásának új lehetőségei. Networkshop. 2013.

Komenczi B. (2009): Elektronikus tanulási környezet. Gondolat Kiadó, Budapest.

* Az Eszterházy Károly Egyetem Médiainformatika Intézetében működő IKT Kutatócsoport által készített kézikönyv célja, hogy gyakorlati tanácsokkal szolgáljon a digitális átállás megvalósítására a mobileszközök használatával, mindhárom platformon (iOS, Android, Windows). A kiadvány ingyenes. URL: http://byod.ektf.hu/produktumok/kiadvanyok 
Molnár G. (2011): Az információs-kommunikációs technológiák hatása a tanulásra és az oktatásra. Magyar Tudomány, 9. sz., 1042-1043.

Molnár P. és Kárpáti A. (2009): Az együttmüködő tanulás támogatása az oktatási informatika eszközeivel: MapIt vitatérkép. Új Pedagógiai Szemle, 59, 2. sz., 49.

Racsko R. (2012): Alternatívák az elektronikus tanulási környezetek kialakítására. Tudományos és müszaki tájékoztatás, 59, 2. sz.

Racsko R. (2014): Összehasonlító pedagógiai kutatások szükségessége az új tanulási környezetek bevezetésében a humán teljesítményt támogató technológiai kutatások szemszögéből. In K.-T. L. Bárdos Jenő: $U_{j}$ kutatások a neveléstudományokban 2013: Változó életformák, régi és új tanulási környezetek. Líceum Kiadó, Eger. 221-239.

Racsko R. és Herzog C. (2015): Egy táblagéppel támogatott pedagógiai kísérlet tanulói és szülői háttérvizsgálata. In: T. J. (szerk.): Százarcú pedagógia.
International Research Institute s.r.o, Komarno. 81-94.

Racsko, R., Kis-Tóth, L. és Gulyás, E. (2014): Változó tanulási környezetek és módszerek. Új kutatások a neveléstudományokban 2014: Oktatás és nevelés Gyakorlat és tudomány. 131-146.

Sántha K. (2006): Mintavétel a kvalitatív kutatásokban. Gondolat Kiadó, Budapest. Kutatatásmódszertani kiskönyvtár.

Sántha K. (2015): Trianguláció a pedagógiai kutatásban. Eötvös József Könyvkiadó, Budapest.

Stolovitch, H. és Keeps, E. (1999): What is Human Performance technology? In H. Stolovitch és E. Keeps: Handbook of Performance Improvement Technology. Jossey-Bass, San Francisco. 3-23.

Time/Qualcomm TIME Invention Poll, in Cooperation with Qualcomm Summary (2013). Forrás: https:// www.qualcomm.com/invention-poll

\section{Jegyzetek}

${ }^{1}$ Ezen a külföldön használatos K12 korosztályt értjük.

${ }^{2}$ A kifejezés a média világából került be a köztudatba. A digitális müsorszórásra való átállás kapcsán kezdték használni. Hazánkban sok esetben digitális transzformáció néven emlegetik ezt a jelenséget, és elsősorban a felsőoktatásra fókuszálnak a kérdésben. Ennek oka lehet az az európai uniós kezdeményezés (http://www.dtransform.eu/), amely nemzetközi szinten az Erasmus+ program keretében, Franciaország, Olaszország, Spanyolország az Egyesült Királyság és Magyaroroszág bevonásával igyekszik ezen változást elősegíteni. Úgy véljük azonban, hogy az oktatás széles spektrumát le kell fedni mind IKT-eszközökkel, mind új módszertani elemekkel. Japánban és Dél-Koreában ugyanis néhány évvel ezelőtt elkezdődött egy mára már nagy sikereket elért szisztematikus fejlesztés, amelyben az infrastuktúra kiépítését helyezték elötérbe. Ez magában foglalta a korszerü IKT-eszközök bevezetését, valamint a digitális könyvtárak oktatásba történő integrálását. A módszer neve információorientált oktatás.

${ }^{3}$ A modell és a korábbi kutatások összefoglalását lásd Kis-Tóth Lajos: BYOD: Az oktatás támogatásának új lehetőségei. http://nws.niif.hu/ncd2013/docs/ ehu/050.pdf

${ }^{4}$ Afreen, Rahat (2014): Bring your own device (BYOD) in higher education: Opportunities and challenges. International Journal of Emerging Trends \& Technology in Computer Science, 3.1: 233-236.
Song, Y. (2014): "Bring Your Own Device (BYOD)" for seamless science inquiry in a primary school. Computers \& Education, 74, 50-60. DOI: 10.1016/j.compedu.2014.01.005

Lennon, R. G. (2012): Bring your own device (BYOD) with cloud 4 education. In Proceedings of the 3rd annual conference on Systems, programming, and applications: software for humanity. ACM, $171-180$

Nykvist, S. S. (2012): The trials and tribulations of a BYOD science classroom. In Proceedings of the 2nd International STEM in Education Conference. Beijing Normal University, 331-334.

${ }^{5}$ A tanárképzés területén, és a szociálpedagógus képzésben természetesen már a 70-es évektől szerepelnek tanegység szinten ilyen ismeretek, például vezetési ismeretek, szervezetfejlesztés.

${ }^{6}$ A kutatási eredmények ugyanis mutatják, hogy az iskolában megtanult ismeretek a mindennapi életben nehezebben transzferálhatók, és hátterében többek között a hazai szigetszerü oktatási módszerek és az elszigetelt ismeretelemek állnak. A problémamegoldás újfajta modellje - a PISA múveltségkoncepcióját (OECD, 2010) beleszőve - tíz éve készült el.

${ }^{7}$ Az eszközök hazavitelének kérdése hazánkban az eszközbiztosítások kidolgozatlansága és az anyagi felelősség vállalásának kérdése miatt nem tisztázott. 